\title{
EDUCAÇÃO CIENTÍFICA, PENSAMENTO CRÍTICO E ARGUMENTAÇÃO: RELATOS DE UMA EXPERIÊNCIA COM LIVROS DE SAGAN E DAWKINS NO ENSINO MÉDIO
}

\author{
Ricardo Roberto Plaza Teixeira 1 \\ ${ }^{1}$ Instituto Federal de São Paulo (IFSP), Campus Caraguatatuba \\ rrpteixeira@bol.com.br
}

Artigo submetido em 10/09/2012 e aceito em 27/09/2012.

\section{RESUMO}

Este artigo analisa diferentes aspectos dos livros "O mundo assombrado pelos demônios", escrito pelo físico Carl Sagan, e "Deus, um delírio", escrito pelo biólogo Richard Dawkins, bem como suas possibilidades didáticas no ensino médio. Ambos os livros são obras de divulgação científica nas quais o tema central é o desenvolvimento do pensamento crítico e a reflexão sobre temas controversos que podem colaborar para a formação de consciências críticas no ensino médio. Esses livros, além disso, apresentam uma interface abrangente muitos temas científicos e também tópicos de história da ciência.
A linguagem utilizada neles evidencia para o leitor como se estrutura um texto argumentativo no qual o objetivo principal é o de persuadir. Esses livros foram lidos por alunos de uma turma de terceiro ano do ensino médio, do Instituto Federal de São Paulo, em uma disciplina- projeto cujos eixos eram Ciência, História e Cultura. $\mathrm{O}$ trabalho pedagógico realizado é analisado a partir dos relatos dos próprios estudantes coletados durante o processo de avaliação da disciplina-projeto.

PALAVRAS-CHAVE: Argumentação; Educação Científica; História da Ciência; Pensamento Crítico.

\section{Scientific education, critical thinking, and arguments: accounts of experience with the medical education literature by Dr. Sagan and Dr. Dawkins}

\section{ABSTRACT}

This article analyses different aspects of the books "The demon-haunted world" written by the physicist Carl Sagan and "The God delusion" written by the biologist Richard Dawkins as well as their educational possibilities in secondary education. Both books are works of
The language used in these books shows for the reader how the argumentative structure is build with the main objective to persuade. These books were read by students in a class of third year of high school at São Paulo Federal Institute in a project-discipline whose axes were Science, 


\section{TEIXEIRA (2012)}

popular science in which the central theme is the development of critical thinking and the reflection on controversial topics. They may contribute to the formation of critical consciousness in high school. These books also have a great interface with many scientific topics and with topics of history of science.
History and Culture. The pedagogical work done is analyzed from the students' own reports in the evaluation process.

KEY-WORDS: Palavras-chave em inglês (abstract e keywords), devendo ser fiel ao original em português. 


\section{EDUCAÇÃo CIENTÍFICA, PENSAMENTO CRÍTICO E ARGUMENTAÇÃO: RELATOS DE UMA EXPERIÊNCIA COM LIVROS DE SAGAN E DAWKINS NO ENSINO MÉDIO}

\section{INTRODUÇÃO}

Um dos mais importantes objetivos dos processos educativos é a formação da aptidão para o pensamento crítico e para a autonomia intelectual. Na década de 1990, Jacques Delors (1997), no Relatório para a UNESCO da Comissão Internacional para a Educação do século XXI, estabeleceu os quatro pilares fundamentais para a educação das crianças e dos jovens: aprender a conhecer; aprender a fazer; aprender a viver; aprender a ser. Uma destas aprendizagens, a do "aprender a ser", permite desenvolver melhor a personalidade do aluno, para que ele possa ter autonomia e comunicar-se argumentando de forma correta a respeito de seus pontos de vista, estimulando a sua curiosidade intelectual, desenvolvendo o seu senso crítico, compreendendo o mundo real, discernindo e tomando decisões de modo consciente e independente. Assim sendo, formar consciências críticas é uma das tarefas fundamentais em todo processo educativo. Os Parâmetros Curriculares Nacionais para o Ensino Médio - PCNs (BRASIL, 1999) destacam que a educação deve privilegiar a formação de consciências críticas, sendo que uma das grandes competências que devem ser valorizadas é a capacidade de argumentação, de forma que o cidadão em formação seja capaz de apresentar e defender os seus próprios pontos de vista. Os PCNs também enfatizam que o trabalho, usando a história da ciência, permite mostrar as controvérsias e os debates que foram enfrentados pela humanidade ao longo do desenvolvimento científico, problematizando questões reais, inclusive aquelas para as quais ainda não há respostas. Finalmente, os $\mathrm{PCN}$ também valorizam atividades que visam desenvolver o hábito e o prazer pela leitura.

O trabalho em sala de aula, por parte do professor, pode incentivar decisivamente uma postura racional diante das questões do cotidiano postas pela vida. Um dos principais papéis do educador - muito mais do que ser apenas um transmissor de conhecimento - é o de incentivar o aluno a buscar outras fontes de informações e outros pontos de vistas, de forma que ele possa discutir com independência sobre o tema pesquisado, estruturando os seus próprios argumentos (MILANESI, 1989). Sendo, essencialmente, uma atividade criativa, é fundamental que o aprendizado se transforme em um processo de autodescoberta e, para isso, o educador tem que levar em consideração a mente, o "coração", os questionamentos, as aflições e as dúvidas do aprendiz (LOWEN, 1997).

Para Piaget (1964), a educação tem como objetivo formar mentes que possam ser críticas e que possam verificar as proposições, em vez de aceitar tudo que lhes é oferecido. A razão, compreendida como o exercício de uma faculdade mental em conformidade com um certo conjunto de regras, está associada a uma forma privilegiada de argumentar que deve ser aprendida no processo educativo (SMITH, 2002) e que deve exercitar a curiosidade, convocando para a imaginação, a intuição, as emoções, a capacidade de conjeturar e a criatividade (FREIRE, 1996).

De acordo com Popper (2001), é fundamental adotar uma atitude altamente crítica em relação àquelas teorias que mais admiramos e tal postura deve ser incentivada pela educação. Para Popper só é possível aceitar alegações que possam ter alguma chance 


\section{TEIXEIRA (2012)}

de serem falsas, ou seja, que possam ser falseáveis. A imperfeição da ciência é uma das suas propriedades mais interessantes, e uma educação científica não pode deixar este ponto de lado (MORRISON, 2001). Portanto, um pensamento crítico e reflexivo (DEWEY, 1959) implica no cuidadoso exame de toda crença ou hipótese, exame esse efetuado à luz dos argumentos e das evidências que a apoiam e das conclusões a que se chega: este modo de pensamento é capaz de produzir um conhecimento sólido baseado em evidências experimentais e em raciocínio lógico. O caminho para este conhecimento envolve passos metódicos que começam pela observação e têm continuidade na ordenação de hipóteses, no estabelecimento de inferências e na submissão de conclusões a provas. Ao comparar as ideias em conflito, mantêm-se apenas aquelas que sobrevivem a uma comparação racional.

Educar é também superar visões de senso comum ingênuas e sem base empírica. O senso comum é constituído de crenças que precedem a reflexão científica e filosófica (LANDESMAN, 2002). O princípio da dúvida metódica como método de pensamento também leva à independência intelectual. A melhor maneira de obter um conhecimento sólido sobre a realidade é, primeiro, acostumarmo-nos a duvidar de todas as coisas (DESCARTES, 1985). Isto ocorre porque as experiências do cotidiano nos brindam sempre com anomalias, incongruências e contradições, de modo que muitas das explicações, à primeira vista razoáveis, são insatisfatórias se analisadas com maior profundidade e cuidado (PEREIRA, 1993). O indivíduo dotado de senso crítico possui a capacidade de analisar problemas racionalmente, sem aceitar de forma automática qualquer opinião (CARRAHER, 1999) e estando sempre propenso a avaliar todas as evidências. Bertrand Russell (apud NAVEGA, 2005) expressou com ironia essa ideia ao afirmar que nuca se proporia a morrer por suas crenças, pois poderia estar errado.

Os textos de divulgação científica podem ser bastante propícios para a tarefa de incentivar a formação de consciências críticas. Nos bons textos de divulgação científica, a prosa é flexível e o seu atrativo mais imediato é que eles despertam autêntico prazer no leitor, independentemente do tema (MORA, 2003). Como a ciência estrutura-se em rede é possível ir de quase qualquer nó desta rede para qualquer outro nó, mesmo por caminhos tortuosos: em muitas das suas lacunas estarão os problemas reais para a ciência, os problemas em aberto para os quais não há respostas e que podem se tornar ferramentas potentes para o desenvolvimento de um verdadeiro espírito de investigação científica. A mudança rápida é a principal característica do nosso tempo acelerado de modificações. Com o volume de conhecimentos científicos crescendo exponencialmente, a pergunta principal no contexto de uma educação científica significativa cada vez mais será: como sabemos o que sabemos? Assim sendo, as evidências experimentais e as inferências racionais para sustentar hipóteses são o assunto por excelência da ciência e da educação científica (MORRISON, 2001).

Em uma sociedade democrática e tecnológica, a alfabetização científica dos cidadãos é fundamental para tomar decisões. Tanto a ciência quanto a democracia necessitam da liberdade de pensamento e de expressão. Para Ann Druyan,

a ciência é o grande conjunto de que precisamos desesperadamente para detectar a falta de bom-senso. Por quê? Porque nossa maior força como uma espécie também é nossa maior fraqueza. Somos criativos, mas também somos terríveis mentirosos. Mentimos para evitar que as outras pessoas tomem o poder. Mentimos para nos fazer sentir especiais, para jogar fora desgastantes ansiedades de mortalidade. Temos um medo terrível de não sermos centrais, de não estarmos sendo vigiados por um 


\section{TEIXEIRA (2012)}

pai carinhoso que nos protegerá e ajudará em nossos medos. Não podemos suportar ou aceitar nossas verdadeiras circunstâncias: que somos pequenos seres em um universo de uma vastidão incompreensível. [...] Essa tendência à autodecepção significa que precisamos de uma máquina que nos mantenha honestos, uma voz que fale em nossos ouvidos, dizendo: 'Tome cuidado agora, você é muito jovem, você é muito ignorante, você é muito novo como uma espécie. Você pensava que isso era verdade antes. Você estava errado. Você pode descobrir mais tarde que outra coisa é verdade'. Precisamos dessa voz em nossa cabeça, e esta voz é a ciência (ANN DRUYAN, 2001, p. 186).

\section{A obra de Carl Sagan}

O físico norte-americano Carl Sagan (1934-1996) foi um dos grandes divulgadores modernos da ciência, tanto nos EUA, quanto em termos mundiais: seu trabalho influenciou muitos jovens pelo mundo afora a estudarem disciplinas científicas. A série de vídeos científicos para a televisão denominada "Cosmos", associada ao livro homônimo (SAGAN, 1992) e lançada inicialmente nos anos 80, tornou-se um modelo de como divulgar com rigor o conhecimento científico para um amplo público leigo e de modo interessante, utilizando-se da linguagem audiovisual. Muito possivelmente, até hoje, no seu gênero, a série "Cosmos" não foi superada. Sagan foi um cientista que se destacou pela sua habilidade literária. Apesar de seu estilo provocador e irônico, nem por isto deixou de se mostrar sempre, em seus escritos, maravilhado pelo universo e pela natureza, passando essa sensação de deslumbramento ao leitor. Em alguns de seus livros anteriores, esse estilo pode ser percebido de forma intensa, sobretudo em "O romance da ciência" (SAGAN, 1989), "Os dragões do Éden" (SAGAN, 1997b), que foi ganhador do prêmio Pulitzer, e "Pálido ponto azul" (SAGAN, 1996b). Mas foi em suas duas últimas obras que esse seu estilo atingiu o apogeu: "O mundo assombrado pelos demônios" (SAGAN, 1996a) e, finalmente, "Bilhões e bilhões" (SAGAN, 1998). "Bilhões e bilhões" é um livro forte no qual Sagan discute, sem meias palavras, utilizando o utilizase do método científico para se posicionar a respeito de assuntos e problemas tão díspares e delicados como o efeito estufa e o direito ao aborto, evidenciando a sua forma de pensar e de agir segundo a qual o cientista pode - e deve - se engajar inclusive em questões políticas, aja visto que é importante que ele tenha um profundo senso de responsabilidade social (TEIXEIRA, 2000). Nesse livro, como em outras das suas obras, ele mostra a importância do papel do cientista como divulgador da ciência e da história da ciência. Para Sagan (1997a), é o grande desafio para o divulgador da ciência deixar bem clara a história real e tortuosa das grandes descobertas, os equívocos e a relativamente frequente recusa obstinada de seus profissionais em tomar outros caminhos.

No que diz respeito ao elogio ao "ceticismo da ciência" como postura de vida e como o melhor método autocorretivo para a vida em uma sociedade democrática, a obra que melhor define Sagan é, sem sombra de dúvida, "O mundo assombrado pelos demônios" (em inglês "The demon-haunted world"). Esse livro, que tem 25 capítulos, foi editado no Brasil pela Companhia das Letras, em 1996 e foi, posteriormente, reeditado pela mesma editora em versão de bolso e popular em 2006. Muitos dos temas mais caros a Carl Sagan são discutidos sistematicamente por este livro, principalmente seu fascínio pela astronomia e, particularmente, por questões relacionadas à origem da vida 


\section{TEIXEIRA (2012)}

na Terra e à possibilidade de existência de vida fora da Terra. O subtítulo desse livro - "A ciência vista como uma vela na escuridão" - evidencia o papel que a razão e o método científico têm para Sagan no enfrentamento às diferentes forças obscurantistas que são descritas ao longo de seu livro: a história da Santa Inquisição tem, por exemplo, uma interessante abordagem no capítulo 24 ("Ciência e bruxaria").

No prefácio de "O mundo assombrado pelos demônios", Sagan (1996a, p. 9) faz uma interessante reflexão sobre seus antigos professores de disciplinas científicas: "Gostaria de poder lhes contar sobre professores de ciência inspiradores nos meus tempos de escola primária e secundária. Mas, quando penso no passado, não encontro nenhum. Lembro-me da memorização automática da tabela periódica dos elementos, das alavancas e dos planos inclinados, da fotossíntese das plantas verdes, e da diferença entre antracito e o carvão betuminoso. Mas não me lembro de nenhum sentimento sublime de deslumbramento, de nenhum indício de uma perspectiva evolutiva, nem de coisa alguma sobre ideias errôneas em que outrora todos acreditavam. [...] Não havia nenhum encorajamento para seguir nossos interesses, intuições ou erros conceituais. Nas páginas finais dos livros didáticos, havia material visivelmente interessante. $\mathrm{O}$ ano escolar acabava sempre antes de chegarmos até aquele ponto. Podiam-se encontrar livros maravilhosos sobre astronomia nas bibliotecas, por exemplo, mas não na sala de aula".

Para Sagan, a educação científica deveria incentivar ao mesmo tempo - e dialeticamente - o pensamento crítico e a capacidade de admiração perante o universo. O juramento de cidadania ideal para ele deveria ser: "Prometo usar as minhas faculdades críticas, a minha independência de pensamento e me educar de modo a poder formar as minhas próprias opiniões". Para tanto, ele destaca, sobretudo, o princípio da navalha de Ockham, segundo o qual uma hipótese deve ser destituída de todas as características que não sejam absolutamente necessárias para fornecer uma explicação dos fatos observados (PEIRCE,1997), ou seja, entre duas explicações, aquela mais simples é a preferível - e o princípio da refutabilidade (falseabilidade), tal como definido por Popper segundo 0 qual, somente afirmações falseáveis que podem ser verificadas experimentalmente podem ser aceitas racionalmente. Os dois principais capítulos de "O mundo assombrado pelos demônios" que fazem referência a essas ideias, com certeza são "O dragão na minha garagem" (capítulo 10) e "A arte refinada de detectar mentiras" (capítulo 12). Nesses capítulos, Sagan deixa claro que a pseudociência, apesar de parecida com a ciência, se diferencia desta pelo fato de não ser falseável.

A grande ideia-força de "O mundo assombrado pelos demônios" é a de que a ciência e a democracia podem se reforçar mutuamente, pois ambas estão assentadas fundamentalmente no mesmo método: a base de ambas está na liberdade em fazer perguntas - "onde há dúvida, há liberdade". Desde modo, o último capítulo de "O mundo assombrado pelos demônios" é denominado significativamente "Os verdadeiros patriotas fazem perguntas".

\section{A obra de Richard Dawkins}

O biólogo britânico Richard Dawkins - nascido no Quênia em 1941 - tem sido o principal divulgador da ciência na área da biologia nas últimas décadas, talvez apenas rivalizado pelo já falecido paleontologista norte-americano Stephan Jay Gould. Atualmente Dawkins é visto por muitos como um sucessor de Sagan na área da divulgação científica em geral. Seu trabalho como cientista tem se destacado na 


\section{TEIXEIRA (2012)}

interpretação da evolução das espécies, a partir do papel central que o gene realiza neste processo, ideia esta que foi inicialmente exposta em seu célebre livro "O gene egoísta" (DAWKINS, 1997) que foi escrito em 1975. Para Dawkins, os genes são de fato as unidades para as quais a seleção natural ocorre. A seleção dos indivíduos mais bem adaptados ocorre a partir da seleção dos genes que produzem os fenótipos associados às características adaptativas desses indivíduos. Assim sendo, a competição darwiniana se dá verdadeiramente entre os genes que são possuídos pelos organismos, e não pelos organismos em si. Outro raciocínio importante postulado por Dawkins em analogia aos genes foi a ideias dos memes; da mesma forma como os genes estão associados à herança biológica, os memes estão associados à herança cultural: ideias, costumes, hábitos, crenças e tradições que podem se comunicar entre si, cooperando e competindo. Tanto os genes quanto os memes são replicadores que são copiados e passados adiante para as próximas gerações, podendo sofrer mutações neste processo. A própria religião seria um meme, assim como as leis, as línguas e a cultura em geral. Em seus livros, Dawkins costuma fazer interessantes contraposições entre evolução genética (biológica) e evolução memética (cultural).

Richard Dawkins estimula em seus livros o uso do pensamento crítico e a procura por evidências experimentais como ferramentas de análise minuciosa em contraposição a uma credulidade ingênua em relação a qualquer alegação; para ele, devemos, por todos os meios, ter a mente aberta, mas não tão aberta a ponto que nossos cérebros possam escapar! Os fatos - e não os homens - é que devem passar pelo crivo da argumentação lógica e científica. Desse modo, os fenômenos que não são compreensíveis - inclusive aqueles classificados como sobrenaturais - devem ser estudados de forma que todas as hipóteses sobre a sua natureza sejam avaliadas e testadas as suas possíveis explicações.

Richard Dawkins escreveu vários livros de divulgação científica para o público leigo, nos quais além da evolução e do darwinismo, são discutidos temas como o criacionismo, o papel da religião no mundo moderno, o ateísmo, a importância do ceticismo, a educação científica e a beleza da ciência. Em 2005, a revista Prospect fez um levantamento sobre quais seriam os maiores intelectuais vivos e Dawkins ficou no terceiro posto, atrás somente de Umberto Eco e de Noam Chomsky. Dawkins recebeu, também em 2005, o prêmio Shakespeare devido a sua apresentação acessível do conhecimento científico para o público leigo em geral. Ele leciona a disciplina "Compreensão pública da ciência" na Universidade de Oxford. Entre suas principais obras de divulgação estão "O relojoeiro cego" (DAWKINS, 2001), "O rio que saía do Éden" (DAWKINS, 1996), "A escalada do monte improvável" (DAWKINS, 1998), "Desvendando o arco-íris" (DAWKINS, 2000) e "O capelão do diabo" (DAWKINS, 2005). Seus livros têm um estilo persuasivo de argumentação sem concessões a qualquer assunto ou autoridade.

Seu livro mais polêmico é, com certeza, "Deus, um delírio" (DAWKINS, 2007) - em inglês "The God delusion" -, que tem provocado um grande impacto e reações entusiásticas em muitos leitores de diversos países. Esse livro tem 10 capítulos e foi editado no Brasil pela Companhia das Letras. A partir de uma pergunta provocadora - "o mundo não estaria melhor sem as religiões?" - o livro tenta elaborar uma discussão racional a respeito dos argumentos, dos fatos e das evidências que existem tanto para alegação da existência de Deus quanto para a alegação da não existência de Deus. Para Dawkins (2007), a alegação a respeito da existência de Deus - e até mesmo da sua probabilidade - deve ser avaliada com a mesma deferência com que outras alegações são feitas, sem condescendências. Ele faz uma crítica demolidora ao fundamentalismo e 


\section{TEIXEIRA (2012)}

ao fanatismo existentes em diversas denominações e vertentes religiosas (cristãos, muçulmanos, judeus, etc.) em diferentes partes do planeta. Como esse movimento fundamentalista generalizado pode provocar um retrocesso para a humanidade, para Dawkins, ele deve ser combatido. No capítulo quinto - "As raízes da religião" - e no capítulo final - "Uma lacuna muito necessária" - de seu livro, o autor elabora um raciocínio evolutivo e "memético" para tentar explicar o surgimento do sentimento religioso e o desenvolvimento das religiões em termos da adaptação e da sua utilidade para a espécie humana. O documentário apresentado em 1996, por Dawkins para a televisão britânica (o Channel Four) e intitulado "The root of all evil", foi uma das bases para a elaboração do livro "Deus, um delírio". A sua fina e mordaz ironia inglesa pode ser percebida neste livro, mesmo com a sua tradução para o português: o primeiro capítulo de "Deus, um delírio" chama-se, curiosamente, "Um descrente profundamente religioso" enquanto o trecho final do seu último capítulo é intitulado, provocativamente, de "A mãe de todas as burcas".

Os dois principais capítulos de "Deus, um delírio" são o terceiro capítulo, "Argumentos para a existência de Deus", e o quarto capítulo, "Por que quase com certeza Deus não existe". Dawkins propõe nesse livro uma escala sobre a probabilidade com que cada um encara a existência de Deus (desde 0 até 100\%): cada pessoa poderia se posicionar nesta escala, de acordo com seus próprios pontos de vista. Essa é uma interessante proposta para abordar, formatar e esquematizar o problema sobre a existência ou não de Deus, mas, obviamente, não para resolver esse problema.

\section{Metodologia do trabalho didático desenvolvido}

"O mundo assombrado pelos demônios" e "Deus, um delírio" são dois livros gostosos de ler, que estimulam o raciocínio crítico, que têm uma linguagem acessível e que apresentam um grande potencial pedagógico. A partir deste pressuposto, surgiu a possibilidade, no ano de 2008, de incluir a leitura desses dois livros em uma disciplinaprojeto do terceiro ano do ensino médio ministrada pelo autor deste artigo, no Centro Federal de Educação Tecnológica de São Paulo (atual Instituto Federal de São Paulo IFSP), na sua unidade sede, na cidade de São Paulo. Essas disciplinas-projeto eram disciplinas regulares e obrigatórias do Ensino Médio com 4 aulas semanais seguidas, de 45 minutos cada uma, e que apresentavam um eixo temático próprio, definido pelo professor, e que permitia uma maior liberdade de ação por parte de professores e de alunos. A disciplina-projeto, em questão, teve como tema "Ciência, História e Cultura" e pretendeu trabalhar questões importantes relacionadas à história da ciência e às controvérsias e polêmicas associadas a essa história. A fundamentação teórica para essas disciplinas-projeto foram as ideias expostas por Fernando Hernández e Montserrat Ventura (1998, p. 61) no livro "A organização do currículo por projetos de trabalho", segundo o qual:

\footnotetext{
"A função do projeto é favorecer a criação de estratégias de organização dos conhecimentos escolares em relação a: 1) o tratamento da informação, e 2) a relação entre os diferentes conteúdos em torno de problemas ou hipóteses que facilitem aos alunos a construção de seus conhecimentos, a transformação da informação procedente dos diferentes saberes disciplinares em conhecimento próprio".
} 


\section{TEIXEIRA (2012)}

A turma que cursou essa disciplina tinha 23 alunos matriculados, com idade entre 17 e 18 anos. Nesse ano letivo, existiram várias turmas de $3^{\circ}$ ano do ensino médio no IFSP, cada uma com uma disciplina-projeto com um tema central diferente, e os alunos optaram pela disciplina-projeto que iriam cursar no final do ano anterior. Essas escolhas foram feitas levando em consideração as vontades manifestadas pelos alunos, bem como suas notas, pois cada turma tinha um número máximo de estudantes. Para $022^{\circ}$ bimestre do ano letivo, foi proposta, como atividade central do curso, a leitura e a apresentação dos livros "O mundo assombrado pelos demônios" e "Deus, um delírio". A classe foi dividida em 6 grupos com entre 3 e 4 alunos em cada grupo. Cada um dos dois livros foi dividido em três partes: para o livro "O mundo assombrado pelos demônios", a $1^{\text {a }}$ parte foi do capítulo 1 ao 8 , a $2^{\text {a }}$ parte foi do capítulo 9 ao 16 e a $3^{\text {a }}$ parte foi do capítulo 17 ao 25; para o livro "Deus, um delírio", a $1^{\text {a }}$ parte foi do capítulo 1 ao 3, a 2a parte foi do capítulo 4 ao 6 e a 3a parte foi do capítulo 7 ao 10. Em cada semana de aula, um dos grupos ficou responsável por apresentar para a classe - usando, inclusive, recursos audiovisuais como televisão, vídeo e projetor multimídia ligado a computador com internet - as ideias básicas daqueles capítulos definidos para o seu grupo. Mas todos os alunos tiveram que ler os livros na totalidade inteiros independentemente dos capítulos escolhidos para os seminários. Além destes seminários, como segunda avaliação bimestral, os alunos tiveram que escrever uma carta ao professor analisando os livros lidos e argumentando a respeito das qualidades e dos problemas que foram encontrados durante a sua leitura.

No início do bimestre, como estratégia de motivação, os alunos assistiram e debateram o filme "O vento será tua herança" que apresenta a história do professor de biologia John Scopes que, na década de 1920, foi proibido de ensinar a teoria da evolução em uma cidade do estado norte-americano do Tennessee, devido a uma lei estadual que proibia o ensino da evolução baseada no argumento, alegado na época, de que a teoria de Darwin se contrapunha às sagradas escrituras. No final do bimestre, os estudantes também assistiram os dois primeiros capítulos da série Cosmos, "Os limites do oceano cósmico" (título em inglês: "The shores of the cosmic ocean") e "A origem da vida" (título em inglês: "One voice in the cosmic fugue"), que discutem de forma bem aprofundada questões associadas às origens da vida na Terra e às possibilidades de existência de vida em outros planetas. Para conhecerem melhor o trabalho de Carl Sagan, eles assistiram também ao filme de ficção-científica intitulado "Contato", baseado na obra homônima de Carl Sagan (1997a) e que discute indiretamente vários dos temas com os quais o autor trabalha em "O mundo assombrado pelos demônios". Todas essas atividades foram pensadas de modo a complementar a leitura e os seminários sobre os dois livros.

\section{Resultados}

As cartas de análise dos dois livros se mostraram uma interessante forma de avaliação e permitiram - muito mais que os seminários - conhecer a argumentação e os pontos de vista de cada aluno sobre esses livros. Foi esclarecido deixado claro durante o curso que o que importava nessas cartas - e nas notas obtidas pelos alunos para essa avaliação - era a capacidade de argumentação sobre os livros e não os pontos de vista individuais, favoráveis ou contrários aos autores das duas obras. Os dois livros envolvem questões polêmicas e, em muitos casos, sem resposta, tais como: Existe vida fora da terra? Deus existe? Os estudantes já tinham claro, de início, que não há ainda respostas 


\section{TEIXEIRA (2012)}

definitivas para problemas como esses. Um dos motivos do envolvimento dos alunos, possivelmente, foi o fato de que a problematização proposta envolvia problemas concretos, verdadeiros e em aberto - ao contrário de algumas questões teóricas que são colocadas para os alunos durante o ensino médio e que são cansativas, artificiais, excessivamente abstratas e não motivadoras, pois na verdade não representam problemas reais.

Alguns trechos relevantes das cartas de avaliação dos alunos são apresentados abaixo de modo a revelar a forma como os alunos se apropriaram da leitura dos dois livros e dos temas discutidos neles. Em primeiro lugar é importante apresentar os relatos dos alunos que afirmaram que a leitura das duas obras foi um ato prazeroso:

- Eu achei um prazer trabalhar com estes temas. Muitas janelas se abriram na minha mente, me fizeram pensar e até mudar minha visão sobre certos aspectos.

- O livro de Sagan foi divertido e me serviu para ampliar e fortificar meus argumentos a favor do ceticismo (viva o dragão invisível) e ter uma visão maior sobre a ciência em geral. Ele trabalhou com a importância de sermos céticos com relação a..., bem, tudo. Já o livro de Dawkins apesar de menos divertido que o anterior, foi aquele com que meu grupo trabalhou e apresentou em classe. Este livro causou uma certa polêmica entre alguns dos meus colegas e devo dizer que adoro esse tipo de situação.

Uma característica que foi lembrada por muitos alunos foi que os livros despertaram neles o espírito cético, no sentido de sempre terem uma abordagem crítica e analítica sobre temas e informações que lhes são fornecidos:

- O livro de Sagan em si é simples e fácil de entender. Achei as suas ideias pertinentes e sua visão de ceticismo como ferramenta de vida é ótima. Outra coisa que achei interessante é como ele mostra os medos das pessoas e como, por causa disso, elas se apegam a pseudo-ciências.

- Em relação ao livro de Dawkins, achei a leitura dele bastante importante, pois como já foi dito antes, essa divergência de ideias é importante na hora da formação do senso crítico. O que prejudica as pessoas e a ciência é a religião levada ao pé da letra, de modo extremo.

- Este livros acabam abordando não só assuntos de religião e aceitação de verdades universais incontestáveis. Atacam em grande parte a especulação de fatos extraordinários, quase maravilhosos, o espalhar de notícias sem fundamento lógico ou devidamente estudado, 0 ato de acreditar em qualquer espécie de lenda urbana que se ouça, a atitude das pessoas de acreditar em tudo que é difundido e distorcido pelos filtros sócio-políticos ou de outras naturezas quaisquer que possam existir entre a fonte da informação e o informado final.

- O dragão na minha garagem' é o melhor capítulo do livro de Sagan. Este livro fala sobre várias coisas da atualidade como terapias, por exemplo, em que o terapeuta muitas vezes, mesmo que inconscientemente, acaba implantando memórias falsas em seus pacientes. Além disso, o livro ensina a importância do ceticismo. 


\section{TEIXEIRA (2012)}

- O livro de Dawkins é muito mais provocador que o de Sagan. Dawkins é muito mais direto. Carl Sagan é menos direto e defende a ciência e o pensamento dos seres humanos. O autor critica a pseudociência e mostra como isso afeta quem acredita nessas crenças. Creio que quem lê esse livro é induzido a fazer análises sobre muitas coisas em que acredita e é isso que o autor queria: fazer uma desintoxicação. Seria muito bom se as pessoas lessem livros como este. A população ficaria mais crítica.

- Acho que nem é preciso dizer que "Deus, um delírio" é realmente um livro fantástico. As suas ideias são bem claras e a argumentação forte (e até divertida). Gostei de ter conhecido opiniões diferentes da minha. Talvez o livro tenha mudado um pouco o meu modo de pensar, não acreditar em tudo logo de cara só porque todos acreditam e nem mesmo apresentam um bom argumento daquilo que defendem. Já o livro de Sagan fala muito sobre fatos que circulam por aí levando o nome de ciência, mas na verdade não passam de pseudo-ciência. O livro ajuda a entender isso: como as pessoas estão sujeitas a todas essas mentiras, mas não por culpa delas e sim porque as informações já estão aí e elas não foram preparadas para filtrar e distinguir o que é ciência e o que não é.

Alguns alunos ressaltaram a importância e a força do argumento em uma discussão racional sobre qualquer tema:

- É incrível onde Dawkins chegou. Existem inúmeros sites críticos e apoiadores de suas idéias. Até criaram 'O delírio de Dawkins'. Muitos falam que em 'Deus, um Delírio' ele exagerou, mas algo que me surpreendeu, é que muitos apresentam outras interpretações dos escritos de Dawkins, colocam outras coisas por cima, mas em nenhum lugar eu vi alguém comentando sobre algum erro que ele cometeu. [...] É legal saber que existem mais pessoas com linhas de pensamento que nem a sua.

- O livro de Dawkins tenta nos instigar a parar para pensar e se perguntar não só "será que Deus existe?" como também "por que acredito em Deus?". Dawkins tenta mostrar que muitas vezes acreditamos num Deus porque assim nos foi imposto desde que nascemos, mas nunca nos questionamos se é verdade ou por que acreditamos. Isso ocorre por que a sociedade põe barreiras ao assunto religião, se tornando um assunto que não pode ser discutido. Dawkins critica essa posição e diz que como uma sociedade democrática devemos ter liberdade para falar sobre o assunto e debater sem medo.

- No capítulo 3 do livro de Dawkins, um dos argumentos que mais gostei foi aquele envolvendo a aposta de Pascal que dizia que é melhor acreditar em Deus, já que você possui 2 opções, acreditar ou não, e cada uma das opções leva a duas possíveis respostas, ou você está certo ou está errado. Caso você acredite em Deus, e esteja certo, você terá a vida eterna. Caso você não acredite em Deus e esteja certo, nada irá mudar. Porém, se você não acreditar em Deus, mas estiver errado, você irá para o inferno, e por fim, se acreditar e estiver errado, nada mudará. Esse é um argumento muito interessante, porém é facilmente rebatido por Richard Dawkins, que diz que não é possível "escolher" o lado que você está, ou 


\section{TEIXEIRA (2012)}

seja, escolher entre acreditar ou não acreditar em Deus, isso é algo que acontece, você acredita ou não, não pode mudar isso só porque você quer. Também Pascal diz que você acreditar e estiver errado ou não acreditar e estiver certo nada mudará, mas Dawkins questiona isso, dizendo que se você acreditar, mas estiver errado, estará se privando de muitas coisas (não beber, sexo só depois do casamento, ...). Enfim achei o livro muito interessante pois abre a mente das pessoas, para que estas não fiquem bitoladas somente a uma idéia, muitas vezes imposta por outras pessoas (pais, mestres, mentores, autores, etc), mas que tenha a capacidade de pensar, analisar ambos os lados, de igual para igual, e decidir para que lado irá.

Finalmente, alguns alunos deram ênfase à questão das origens (do universo, da vida, da consciência) e fizeram reflexões interessantes sobre o problema da existência de Deus, inclusive sobre a importância do contraditório e do embate respeitoso de ideias até para fundamentar melhor as próprias opiniões:

- O livro de Dawkins é muito bem redigido, com uma argumentação muito bem elaborada. Por ser muito racional, tenho de concordar com o livro, mas sei que isto é algo que nunca saberemos. Mesmo que a ciência descubra toda a lógica que permeia o universo, sempre esbarraremos na questão do "primeiro motor". Não sabemos de onde veio a matéria. Se dissermos, por exemplo, que energia é capaz de tornar-se matéria, nos perguntaremos de onde veio a energia. Todavia, há um meio de descobrirmos se Deus existe ou não. Basta morrermos. O único problema é que ninguém se lembra de voltar e nos contar como é depois de morrermos. Por isso, penso que as religiões devem ser 'conversáveis', mas nunca impostas.

- No livro de Dawkins, a discussão é sobre se a crença num Deus é algo que pode nos trazer algum bem, ou se pelo contrário, nos traz malefícios, como aconteceu na caça às bruxas, na Idade Média, ou durante as cruzadas, nas quais milhões de pessoas morreram em nome da fé. Nascido no seio de uma tradicional família católica, este livro reforçou minha repulsa às grandes religiões onipotentes. Não obstante, minha crença deísta em algum ser superior não foi alterada. Já o livro de Sagan conseguiu me tornar mais apaixonado pela ciência, única forma de continuar o progresso mundial, sem rumar para o Apocalipse, não 0 determinado por Deus, mas por nós humanos. Acredito que meus colegas tiveram experiências tão interessantes quanto a minha.

- Eu achei proveitoso o estudo sobre os temas deste bimestre. No meu caso, sou cristão protestante, mais especificamente da Igreja Presbiteriana, e eu não vejo mal em ver outros pontos de vista e ideias contrárias, acho que isso só ajuda no meu crescimento tanto espiritual quanto racional. Eu penso que a ciência e Deus estão extremamente relacionados e, por exemplo, acreditar na teoria da evolução não me impede de acreditar que Deus foi o criador de todas as coisas. É claro, não são todos os da minha denominação que pensam assim; eu pertenço a este lado que acredita que não devemos ignorar fatos e descobertas evidentes por causa de interpretações ao pé da letra da Bíblia, pois a Bíblia não serve para ser "livro de ciências" e sim de Teologia. Mas nem 


\section{TEIXEIRA (2012)}

por isso deixo de conviver e de acreditar em Deus. Os capítulos do livro de Dawkins que apresentei foram bem interessantes. Muitos argumentos de Dawkins foram compatíveis com os meus, como aquele capítulo que fala se é preciso de uma religião para termos noção do que é certo e errado, ambos concordamos que não.

\section{Conclusões}

Uma pesquisa na internet, feita pelo autor desse artigo usando o buscador google em junho de 2008, associou cerca de 3 milhões de páginas ao nome de "Carl Sagan" e cerca de 6 milhões de páginas ao nome de "Richard Dawkins". Para uma melhor ideia da relevância destes números, ao nome Isaac Newton são associadas cerca de 4 milhões de páginas e ao nome de Charles Darwin, cerca de 6 milhões de páginas. No mesmo sentido, Ana Maria Sánchez Mora (2003) inclui livros de Sagan e de Dawkins entre aqueles classificados como bons textos de divulgação científica, pois têm o papel relevante de despertar o prazer no leitor pela ciência e pelo conhecimento.

Os resultados do trabalho realizado em sala de aula envolvendo a leitura dos livros "O mundo assombrado pelos demônios" e "Deus, um delírio" mostraram-se bastante satisfatórios. Uma das razões é a que há um evidente diálogo positivo entre essas duas obras - sobretudo, pela interdisciplinaridade com que os diversos temas são abordados nos textos - o que facilita o uso pedagógico dos dois livros simultaneamente. O caráter aberto da disciplina-projeto permitiu também implementar essas leituras de forma que o professor tivesse liberdade de ação no dia-a-dia da sala de aula. O perfil dos alunos do IFSP que apresentam um alto nível cultural devido à seleção que existe para a entrada dos estudantes em seus cursos, também colaborou com os bons resultados obtidos por este trabalho. Finalmente, 0 fato de os dois livros lidarem com problemas reais $e$ desafiadores, e para os quais ainda não há respostas, foi um motivador adicional para os alunos que se envolveram de forma intensa com os principais temas abordados pelos dois livros, inclusive ampliando o leque de leituras para além daquelas solicitadas pelo professor e desenvolvendo a capacidade de investigação crítica em diferentes fontes de informação a respeito desses temas - como a pesquisa em sítios da internet. Essa experiência indica que mesmo em situações não tão favoráveis, trabalhos similares, com esses ou outros livros, ou mesmo apenas usando alguns de seus capítulos, podem ser implementados produzindo bons resultados.

Analisando a situação da educação científica nos EUA, Michael Apple (2003) apresenta estáticas assustadoras, em se tratando do país mais rico do planeta, que indicam que $47 \%$ dos habitantes dos Estados Unidos acreditam que "Deus criou 0 homem de forma bem parecida a que tem agora num momento qualquer dos últimos 10 mil anos". Dada a importância dos EUA no mundo, esse fato mostra como é importante, em qualquer país, inclusive no Brasil, trabalhar com textos de divulgação científica com este perfil nas escolas.

Uma outra consequência desse trabalho foi o de despertar o prazer e o gosto pela leitura por parte dos alunos, algo significativo no mundo tecnológico de hoje em que onde a imagem é tão mais sedutora que a palavra escrita. Muitos alunos dessa turma, que era de $3^{\circ}$ ano de ensino médio, afirmaram que sentiram muito prazer na leitura dessas duas obras, mesmo tendo que, concomitantemente, ler várias outras obras de literatura brasileira que são obrigatórias para os vestibulares. Dados de uma pesquisa (NUCCl, 2002), com jovens do ensino médio, mostram que o hábito da leitura de livros está bem 


\section{TEIXEIRA (2012)}

abaixo do hábito de leitura de outros veículos impressos em papel (jornais e revistas), e isto bem antes da disseminação em larga escala da internet: esses dados indicam a importância do trabalho com a leitura de livros no ensino médio.

Os principais resultados educacionais desse trabalho foram que:

- os alunos passaram a se interessar mais por temas científicos, mesmo aqueles alunos que prestariam vestibular para cursos de humanidades.

- os alunos ampliaram a visão a respeito da forma como os conceitos da ciência evoluíram ao longo da história, superando uma visão ingênua de que a ciência avança de modo linear e lógico, como muitos manuais e livros didáticos levam a crer.

- os alunos desenvolveram um modo crítico de raciocinar e de pensar (inclusive sobre suas próprias opiniões), procurando não aceitar de forma crédula afirmações - mesmo aquelas proferidas por "autoridades" - e boatos para as quais não há evidências sólidas e que não correspondam à realidade, uma importante ferramenta para a participação responsável na "sociedade da informação" moderna.

- o livro despertou a imaginação e a criatividade para questões até então desconhecidas por muitos dos alunos.

- os alunos desenvolveram o prazer pela leitura de bons livros e aprenderam modos de pesquisar, escolher e descobrir outros livros que podem provocar leituras interessantes.

- as leituras permitiram que os alunos desenvolvessem suas próprias opiniões sobre temas importantes do dia-a-dia e também que desenvolvessem argumentos para sustentar, de forma segura e respeitosa, essas opiniões, dada à diversidade de concepções existentes sobre os temas estudados.

- os alunos desenvolveram a importante ideia civilizatória de que quando se discute algo, está se discutindo sobre conceitos ideias e não sobre pessoas, e que quando você discorda da ideia de alguém, é esta outra ideia que será adversária das suas próprias ideias, e não o seu proponente que será seu adversário.

Para Perrenoud (2000), uma das competências necessárias para ensinar está em envolver os alunos em suas aprendizagens, suscitando o desejo de aprender e explicitando as relações existentes com o saber. Da mesma forma, Rubem Alves (1997, p. 128) afirma: "A tarefa do professor: mostrar a frutinha. Comê-la diante dos olhos dos alunos. Provocar a fome. Erotizar os olhos. Fazê-los babar de desejo. Acordar a inteligência adormecida. Aí a cabeça fica grávida: engorda com ideias. E quando a cabeça engravida não há nada que segure o corpo." O físico Albert Einstein (1954) escreveu também sobre a importância de a educação formar consciências independentes; para ele o desenvolvimento da capacidade geral de pensamento e julgamento independentes deve ser sempre colocado em primeiro plano, sobretudo em contraposição à memorização de conhecimentos específicos. Uma pessoa que domina os fundamentos de sua disciplina e aprende a pensar e trabalhar independentemente consegue encontrar por si só o seu caminho e, além disso, é mais capaz de se adaptar ao progresso e às mudanças do que outra cujo aprendizado tenha consistido, sobretudo, na aquisição de conhecimentos detalhados.

Essas referências salientam o papel-chave que o professor tem em uma educação científica de qualidade. As mudanças efetuadas a partir dos anos 90 , na educação das disciplinas científicas trabalhadas durante o ensino médio, tiveram como objetivo usar a força da motivação do entendimento profundo da ciência e da maravilha que resulta da compreensão do poder e da universalidade de um número relativamente pequeno de princípios científicos fundamentais (ALDRIDGE, 2001). O trabalho descrito aqui foi justamente uma tentativa de colocar essas ideias em prática. 


\section{TEIXEIRA (2012)}

\section{Referências}

ALDRIDGE, Bill G. Ciência e ensino. In: TERZIAN, Yervant e BILSON, Elizabeh. $O$ universo de Carl Sagan. Brasília: Editora da UnB, 2001.

ALVES, Rubem. Cenas da vida. Campinas, SP: Papirus, 1997.

APPLE, Michael W. Educando à direita: mercado, padrões, Deus e desigualdade. São Paulo: Cortez, 2003.

BRASIL. Parâmetros Curriculares Nacionais. Brasília: MEC, 1999.

CARRAHER, D. W. Senso crítico. São Paulo: Pioneira, 1999.

DAWKINS, R. O rio que saía do Éden. Rio de Janeiro: Rocco, 1996.

DAWKINS, R. O gene egoísta. São Paulo: Companhia das Letras, 1997.

DAWKINS, R. A escalada do monte improvável. São Paulo: Companhia das Letras, 1998.

DAWKINS, R. Desvendando o arco-íris. São Paulo: Companhia das Letras, 2000.

DAWKINS, R. O relojoeiro cego. São Paulo: Companhia das Letras, 2001.

DAWKINS, R. O capelão do diabo. São Paulo: Companhia das Letras, 2005.

DAWKINS, R. Deus, um delírio. São Paulo: Companhia das Letras, 2007.

DELORS, J. Educação: um tesouro a descobrir. São Paulo: Cortez, 1997.

DESCARTES, René. The philosophical writings of Descartes. Cambridge: Cambridge University Press, 1985.

DEWEY, John. Como pensamos: como se relaciona o pensamento reflexivo com o processo educativo. São Paulo: Nacional, 1959.

DRUYAN, Ann. A ciência precisa ser popularizada? In: TERZIAN, Yervant e BILSON, Elizabeh. O universo de Carl Sagan. Brasília: Editora da UnB, 2001.

EINSTEIN, Albert. Ideas and Opinions. New York: Crown Publishers Inc., 1954.

FREIRE, Paulo. Pedagogia da autonomia. São Paulo: Paz e Terra, 1996.

HERNÁNDEZ, Fernando e VENTURA, Montserrat. A organização do currículo por projetos de trabalho. Porto Alegre: Artmed, 1998.

LANDESMAN, Charles. Ceticismo. São Paulo: Edições Loyola, 2002.

EIXO, v. 1, n. 2 


\section{TEIXEIRA (2012)}

LOWEN, A . Alegria. São Paulo: Summus, 1997.

MILANESI, L. Ordenar para desordenar. São Paulo: Brasiliense, 1989.

MORA, A. M S. A divulgação da ciência como literatura. Rio de Janeiro: Ed. UFRJ, 2003.

MORRISON, Philip. O ensino da ciência em uma democracia. In: TERZIAN, Yervant e BILSON, Elizabeh. O universo de Carl Sagan. Brasília: Ed. da UnB, 2001.

NAVEGA, Sergio. Pensamento crítico e argumentação sólida. São Paulo: Publicações Intelliwise, 2005.

NUCCI, Eliane Porto di. Letramento: algumas práticas de leitura do jovem de ensino médio. Psicologia escolar e educacional. Campinas, v.6, n.1, jun. 2002.

PEIRCE, Charles Sanders. Pragmatism as a principle and method of right thinking. Albany: State University of New York Press, 1997.

PEREIRA, Oswaldo Porchat. Vida comum e ceticismo. São Paulo: Brasiliense, 1993.

PERRENOUD, Philippe. Dez novas competências para ensinar. Porto Alegre: Artmed, 2000.

PIAGET, Jean. Cognitive development and children. In: RIPPLE, R. e ROCKASTLE, V. (orgs.) Piaget rediscovered: report on the conference of cognitive studies and curriculum development. Ithaca, New York: Cornell University, 1964.

POPPER, Karl. A lógica da pesquisa científica. São Paulo: Cultrix, 2001.

SAGAN, C. O romance da ciência. São Paulo: Francisco Alves, 1989.

SAGAN, C. Cosmos. São Paulo: Francisco Alves, 1992.

SAGAN, C. O mundo assombrado pelos demônios. São Paulo: Cia das Letras, 1996a.

SAGAN, C. Pálido ponto azul. São Paulo: Companhia das Letras, 1996b.

SAGAN, C. Contato. São Paulo: Companhia das Letras, 1997a.

SAGAN, C. Os dragões do Éden. Lisboa: Gradiva, 1997b.

SAGAN, C. Bilhões e bilhões. São Paulo: Companhia das Letras, 1998.

SAGAN, C. O mundo assombrado pelos demônios. São Paulo: Companhia das Letras, 2006.

SMITH, Bárbara H. Crença e resistência. São Paulo: Editora da Unesp, 2002.

EIXO, v. 1, n. 2 


\section{TEIXEIRA (2012)}

TEIXEIRA, R. R. P. e TEDESCHI, W. Os "Bilhões" de Sagan e a educação científica. Sinergia (CEFETSP), São Paulo, v. 01, p. 11-17, 2000. 